\title{
TUGAS FILSAFAT MORAL
}

\section{ANALISIS KASUS YANG TERJADI DALAM KEHDUPAN SEHARI-HARI DI INDONESIA}

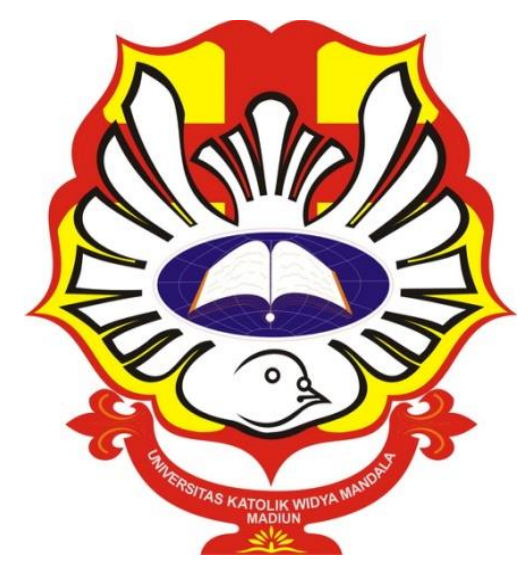

Disusun Oleh:

Semaya Nopianto Ijaka

NIM 51418046

PROGRAM STUDI MANAJEMEN

FAKULTAS EKONOMI DAN BISNIS

UNIVERSITAS KATOLIK WIDYA MANDALA MADIUN

MADIUN 2019 


\begin{abstract}
ABSTRAK
Tujuan dalam analisis kasus ini bahwa jika membunuh sesama manusia tidak memiliki nilai kemanusiaan dan nilai etikanya sebagai umat manusia kita tentu sudah pastinya mempelajari tentang etika dan moralitas. Dalam filsafat manusia juga di pelajar bahwa sebagai makhluk manusia kita tidak boleh membunuh, dalam hal ini juga pelaku tidak mempunyai hati nurani sehingga pelaku berani membunuh korban, sehingga dalam kasus ini juga pelaku sangat tertekan karena sering di ejek korban maka dari itu pelaku membunuh korban. Dalam kasus ini 'motif pembunuhan di Bima terungkap, pelaku mengaku kesal sering diejek' maka dalam hal ini motif awal pelaku karena dendam dan soal asmara juga dari itu pelaku merasa kesal sering di olok-olok dan diejek korban dan juga pelaku mengaku mempunyai rasa dendam sekali dalam hatinya sehingga pelaku membunuh korban karena sakit hati. Maka dalam analisis ini dapat diambil bahwa membunuh adalah tindakan yang memalukan dan tidak ada nilai kemanusiaan.
\end{abstract}

Kata kunci : membunuh, hati nurani, dan moralitas 


\section{A. Motif Pembunuhan Sadis di Bima Terungkap, Pelaku Mengaku Kesal}

\section{Sering Diejek}

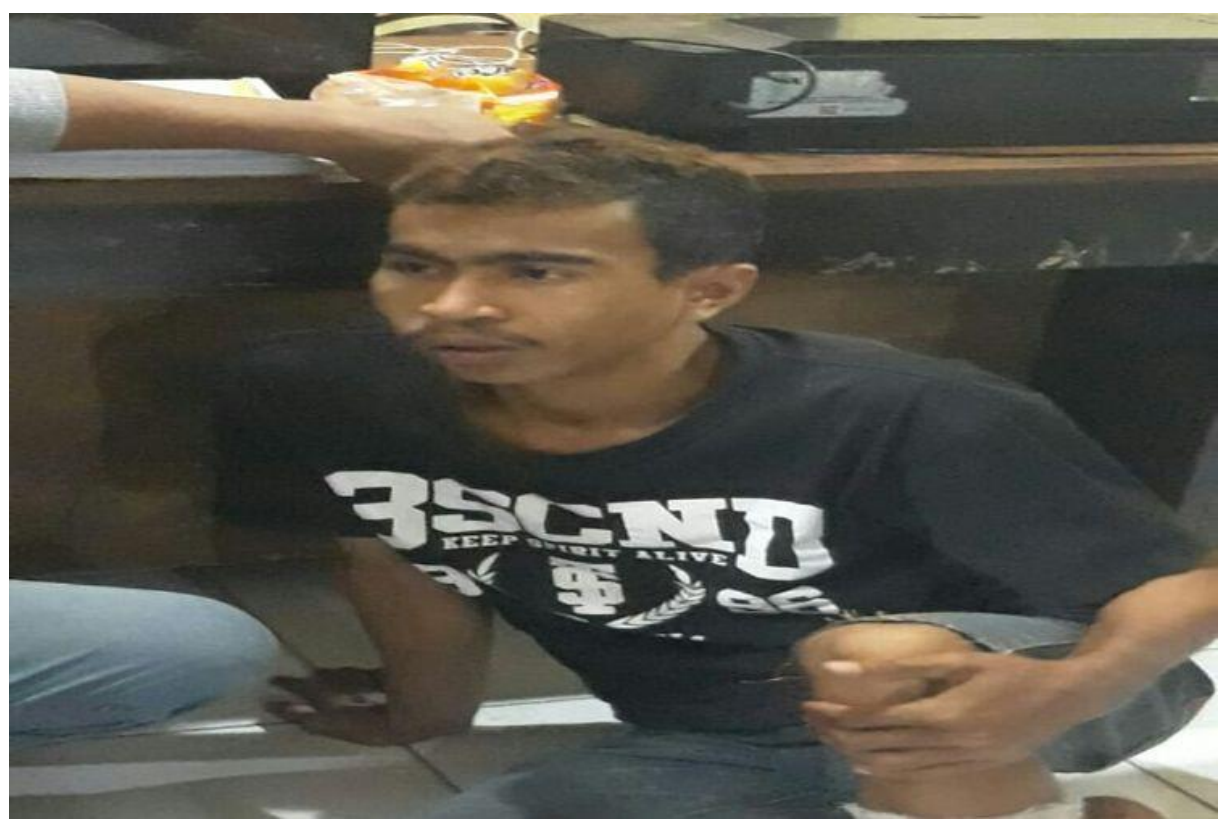

https://regional.kompas.com/read/2019/01/30/17160401/motif-pembunuhansadis-di-bima-terungkap-pelaku-mengaku-kesal-sering-diejek?page=all.

BIMA, KOMPAS.com - Polisi mengungkap kasus pembunuhan sadis yang dilakukan FM terhadap Muamar Ramadhan (23), warga lingkungan Tolobali, Kota Bima, Nusa Tenggara Barat (NTB). Motif pembunuhan ini ternyata dipicu rasal kesal yang dirasakan tersangka FM karena sering diejek korban. Padahal keduanya saling kenal dan berteman dekat Kasat Reskrim Polres Bima Kota Iptu Akmal Novian RezaI mengatakan, motif pembunuhan itu berlatar belakang murni sakit hati. Kepada polisi, FM mengaku tak terima diolok-olok korban. "Dari hasil pemeriksaan awal, untuk motifnya karena dendam dan asmara, seperti ke arah transgender. Pelaku mengaku sering diolok-olok oleh korban sehingga menimbulkan dendam. Pelaku mengakui melakukan eksekusi pembunuhan tersebut," katanya. Diduga, korban sebelum kejadian sering mengejek pelaku. Karena merasa sakit hati, kata Akmal, tersangka pun langsung menghabisi nyawa korban di sebuah rumah warga di lingkungan Lewi Sape, Kelurahan Sarae, pada Senin (21/1/2019) dini hari 
lalu. Baca juga: Sepekan Jadi Buron Polisi, Pembunuh Sadis di Bima Dilumpuhkan Kata dia, pelaku melakukan perbuatan sadis itu dengan cara melukai leher korban dengan pisau cutter. "Pembunuhan dilakukan dalam kamar pada saat korban sedang tidur. Alat yang digunakan pelaku adalah pisau cutter," ujar Akmal saat ditemui di Mapolres Bima Kota.

Rabu (30/1/2019) Setelah melukai leher korban dengan senjata tajam, pelaku lantas menyembunyikan sejumlah barang bukti sebelum kabur. Dari hasil penyelidikan sementara, kasus pembunuhan itu dilakukan secara terencana. Akmal menegaskan, saat ini pelaku telah ditahan di Mapolres Bima Kota. "Untuk pelaku saat ini kami lakukan pendalaman. Barang bukti sudah kami sita berupa pisau cutter dan pakaian yang digunakan pelaku saat membunuh korban," ucapnya. Seperti diketahui, tersangka FM (23) ditangkap pada Selasa (29/1/2019). FM terpaksa dilumpuhkan karena nekat melawan petugas. "Satu pelaku pembunuhan itu berhasil kita tangkap di Desa Lapadi, Kecamatan Pajo, Kabupaten Dompu, sekitar pukul 21.30 Wita," kata Akmal kepada wartawan, Selasa (29/1/2019) malam. Akmal mengatakan, penangkapan pelaku pembunuhan itu berkat laporan dari masyarakat. Petugas kemudian bergerak cepat dan melakukan pengejaran, hingga akhirnya FM diringkus. "Pelaku sempat melawan petugas, sehingga dilumpuhkan," tuturnya. Menurut Akmal, pihaknya berhasil mengungkap kasus pembunuhan terhadap pemuda berusia 23 tahun ini tidak kurang dari satu pekan melakukan penyelidikan dan penyidikan. Polisi harus berjuang keras mengungkap kasus pembunuhan tersebut karena saat kejadian di lokasi penemuan mayat tidak ada barang bukti yang ditinggalkan. Berdasarkan hasil penyelidikan, indikasi pembunuhan sadis itu mengarah ke FM setelah ia berpindah-pindah tempat untuk menghindar dari kejaran aparat, hingga akhirnya FM berhasil diringkus. Kepada polisi, FM mengakui semua perbuatannya. "Kasus ini kami ungkap selama tujuh hari. Keberadaan FM sebelumnya berada di Desa Dena, Kecamatan Madapangga, Kabupaten Bima. Kemudian dia berjalan melintasi gunung menuju Dompu," ujar Akmal. Pelaku pembunuhan tersebut tak disangka ternyata tetangga kampung yang tak jauh dari rumah korban. FM 
tercatat sebagai warga lingkungan Gilipanda, Kelurahan Sarae, Kota Bima. Kini, tersangka tersebut sudah diamankan di Mapolres Bima Kota setelah mendapat perawatan medis di RSUD Bima. "Pelaku telah kami amankan, saat ini masih dilakukan pemeriksaan secara intensif," tutur Akmal. Baca juga: Satu Keluarga Dibunuh, Dimakamkan Berdampingan di Satu Liang Seperti diberitakan sebelumnya, Muamar, seorang warga Tolobali ditemukan tewas mengenaskan pada Senin (21/1/2019). Dari hasil olah TKP polisi, Muamar diduga dibunuh saat tertidur dalam sebuah kamar, bukan di teras seperti disebutkan warga sebelumnya.

\section{B. ETIKA}

Pengertian memaksudkan penjelasan yang lebih luas dan mendalam daripada definisi. Terminologi "etika" secara etilomogis berasal dari Yunani, "ethos", yang berarti "custom" atau kebiasaan yang berkaitan dengan tindakan atau tingkah laku manusia, juga dapat berarti "karakter" manusia (keseluruhan cetusan perilaku manusia dalam perbuatannya).

Ethos memiliki makna "anaction that is one's own”, atau suatu tindakan yang dilakukan seseorang dan menjadi miliknya, makna ethos semacam ini juga dimiliki oleh kata Latin, "mores", yang darinya kata "moral" diturunkan. Dengan demikian ethical dan moral sinonim. Etika adalah filsafat moral. Etika adalah filsafat moral.

Etika berbeda dengan etiket. Jika etika berkaitan dengan moral, etiket hanya tali-tenali dengan sopan santun. Belajar etiket berarti bagaimana bertindak dengan cara-cara yang santun; sedangkan belajar etika berarti begaimana bertindak baik. Lapangan etiket berkisar pada tindakan/cara-cara bertindak dari sudut pandang eksternal, dan tidak menyentuh kedalaman tindakan secara utuh. Etika menunjuk pada tindakan manusia secara menyeluruh. Artinya, etiks tidak hanya bersoal jawab dengan cetusan tindakan lahiriah manusia, melainkan juga motivasi yang mendasarinya dan aneka dimensi lain yang ikut berpatisipasi di dalamnya. Etika, pendek kata, mengantar orang pada bagaimana menjadi baik. 
Secara umum dapat dikatakan bahwa etika adalah filsafat tentang tindakan manusia sebagai manusia. Suatu tindakan itu mempunyai nilai etis bila dilakukan oleh manusia dan dalam kerangka manusiawi. Jelas bahwa etika itu berurusan secara langsung dengan tindakan atau tingkah laku manusia. Tingkah laku manusiawi ini bukan tingkah laku yang tidak ada artinya, tetapi mengejar nilai kebaikan.

\section{PERBEDAAN ANTARA: ACTION OF HUMAN BEING (ACTUS HOMINIS) \& HUMAN ACTION (ACTUS HUMANUS)}

a) Dalam actus hominis, tindakan manusia tampil sebagai suatu gerakan belaka. Dalam tindakan itu manusia berada pada level yang paling rendah, yaitu level vegetatif (level tindakan yang dimiliki oleh semua makhluk hidup yang gerakannya melulu ditentukan oleh desakan natural). Gerakan semacam ini lebih berupa insting, refleks, atau apa saja yang dilakukan oleh manusia sebagai makhluk hidup pada umumnya. Oleh karena itu actus hominis ini berada di luar lapangan penilaian moral. Actus hominis, adalah tindakan fisiik yang dimiliki manusia. Seperti, makan, tidur, minum berlari, dan seterusnya. Harus dikatakan tarafactus hominis ini manusia bertindak sam persis dengan binatang.

b) Tindakan manusia disebut human action (actus humanus) apabila eksistensinya sebagai makhluk rasional tercetus secara menyakinkan. Manusia adalah ciptaan Tuhan yang memesona, karena dianugerahi akal budi. Ini yang tidak dimiliki makhluk hidup lain. Rasio manusia hadir dalam proses tindakannya seperti: perencanaan, pengambilan keputusan, penegasan kehendak, penjabarannya dalam tindakan konkret, dan evaluasi kemudian.

\section{STRUKTUR TINDAKAN MANUSIA}

Tindakan manusia adalah eksekusi dari kehendak. Thomas Aquinas melanjutkan gagasan Aristoteles berkaitan dengan voluntary (tindakan yang dikehendaki) dan involuntary (tindakan yang tidak dikehendaki. Semacam eksekusi kehendak bebas (voluntary) ini pun, Thomas Aquinas 
mengklasifikasikannya dalan dua macam, yaitu: directly voluntary (whatever result from a decision atau apa yang langsung dikehendaki dari keputusan perbuatan itu), dan inderctly voluntary (what result from not willing atau apa yang merupakan konsekuensi tindakan tetapi tidak dikehendaki). Suatu keutamaan dari sendirinya merupakan suatu produksi dari aktivitas yang berulang-ulang directly voluntary.

Direct voluntary adalah kehendak si pelaku itu sendiri. Dengan demikian direct voluntary adalah cetusan dari manusia sebgai subjek dari tingkah lakunya. Mengkehendaki untuk memutuskan suatu tindakan merupakan tindakan untuk mengkomunikasikan dirinya dalam tindakan tersebut. suatu perbuatan yang buruk (seperti membunuh, mencuri, memerkosa, dst). Dalam pertimbangan moral/etis, tidak pernah boleh merupakan direct voluntary.

\section{E. HATI NURANI SESAT}

St.Thomas mengatakan: bila kesesatan hati nurani invincible (tak bisa ditundukkan/tak bisa diatasi) dan inculpable (tak bisa dipersalahkan/tak bisa dihukum), orang dapat luput dari perbuatan yang secara moral jahat. Artinya, bila ia berbuatan jahat atas dorongan hatinya yang sesat invicible and incupable,perbuatan jahatnya secara moral tidak bisa ditanggungkan keadaanya. Jika kesesatannya vincible (bisa diatasi) and culpable (bisa dipersalahkan), tanggung jawab perbuatan buruk/jahatnya ada pada si pelaku.

Kesesatan yang culpable ialah kesesatan mengenai apa yang harus diketahui oleh seorang pribadi (jadi dia mestinya tahu), atau kesesatan itu mengalir dari kelalaian atau kesembronoan pada pihak si pelaku misalnya, karena kesesatan dibiasakan. Bila kesesatan itu berhubungan dengan apa yang harus diketahui. Dengan kata lain, tentang apa yang semestinya dia tahu, tetapi dia tidak mau tahu atau membiarkan diri tidak tahu, dia jelas bersalah. Kesesatan adalah vincible apabila subjek, pada waktu itu, dapat mengkoreksinya. Ini berarti dia (subjek itu) paling sedikit memiliki kecurigaan-kecurigaan tertentu bahwa yang sedang dia lakukan itu tidak 
semestinya atau sewajarnya. Kesesatan adalah culpable apabila itu merupakan produk pemanfaatan kebebasan secara jahat. Culpable apabila pelaku bersihkukuh atau bertaham atau membiarkan diri dalam kesesatan.

\section{F. MENGANALISA KASUS DENGAN TEORI/MENEROPONG TEORI FILSAFAT MORAL}

Dikaji dari filsafat moral mengenai kasus pembunuhan Pembunuhan Sadis di Bima Terungkap, Pelaku Mengaku Kesal Sering Diejek. Dari kasus diatas tentu saja itu melanggar etika. Secara umum dapat dikatakan bahwa etika adalah filsafat tentang tindakan manusia sebagai manusia. Membunuh suatu perbuatan yang buruk dan tentu saja suatu yang melanggar etika. Dimana membunuh suatu perilaku yang melanggar agama, hukum, dan moral. Sebagai manusia kita melakukan suatu tindakan sebagai manusia yang dikaruniai akal budi yang diberikan oleh Yang Mahakuasa. Bukan sebaliknya yang dilakukan pelaku dengan membunuhnya secara tragis. Tindakan yang dilakukan oleh pelaku didasari oleh sering di ejek.

Sebagai manusia seharusnya memiliki tindakan human action (actus humanus) yang merupakan suatu syarat perbuatan moral. Artinya etika berada dalam lapangan perbuatan manusiawi. Sebagaimana manusia ialah ciptaan Tuhan yang memesona, karena ia dianugerahi akal budi yang berbeda dengan makhluk hidup lainnya. Sebagaimana manusia memiliki akal budi tahu mana perbuatan yang baik dan buruk serta benar dan salah. Namun, dari kasus pembunuhuhan sadis di Bima terungkap, pelaku mengaku kesal sering diejek. Sungguh tragis dan suatu tindakan yang tidak mencerminkan human action (actus humanus).

Pelaku melakukan tindakan membunuh, dan menyiksa seperti memperlakukan manusia tidak seperti sebagaimana mestinya. Suatu tindakan tarafactus hominis manusia bertindak sama persis seperti binatang. Actus hominis adalah suatu tindakan yang dilakukan oleh manusia, tetapi tidak selaku manusia yang tahu dan mau secara bebas. Pelaku memperlakukan korban seperti manusia yang tidak memiliki akal budi, pelaku seharusnya 
sadar bahwa tindakan yang dilakukan tersebut merugikan diri sendiri dan orang lain. Sungguh kejam tindakan yang dilakukan oleh pelaku. Tentu saja ini suatu tindakan yang dilakukan tidak memperlakukan manusia selayaknya manusia, pelaku memeperlakukan korban seperti binatang. Perbuatan seperti ini tentu saja bukanlah cerminan sebagai manusia yang berakal budi dan bertanggung jawab atas setiap perilaku atau tindakan yang dilakukan. Pembunuhan, dan penyiksaan yang dilakukan pelaku tentu saja melanggar etika dan tidak mencerminkan human action (actus humanus). Pelaku seharusnya mengerti apa yang Ia lakukan suatu perbuatan yang keliru.

Dengan kehendak bebas yang pelaku miliki sehingga dengan trgais dan kejamnya dia melakukan perbuatan keji tersebut dengan menyiksa, membunuh. Perbuatan yang sungguh tidak terpuji dan tindakan yang dilakukan pelaku seperti manusia yang tidak berakal budi dan merupakan pelanggaran moral, hukum, dan agama. Tentu saja melalui tindakan yang pelaku lakukan harus dipertanggung jawabkan dihadapan hukum yang berlaku. Sebagai manusia selayaknya memeperlakukan manusia sebagai manusia dengan saling menghormati, menghargai, mengasihi dan perbuatan positif lainnya. Rasionalitaslah yang membedakan manusia dengan makhluk hidup lainnya. Inilah tindakan manusiawi human action (actus humanus), manusia yang memiliki cita-cita tujuan dan sebagai tuan dan pemilik atas perbuatannya sendiri.

Struktur tindakan manusia dibagi menjadi dua yaitu voluntary (tindakan yang dikehendaki) dan involuntary (tindakan yang tidak dikehendaki). Mengenai eksekusi kehendak bebas Aquinas membagi dalam dua macam yaitu, directly voluntary apa yang langsung dikehendaki dari keputusan itu dan inderectly voluntary apa yang merupakan konsekuensi tindakan tetapi tidak dikehendaki.

Dari kasus tersebut motif pembunuhan yang di lakukan oleh pelaku dikenal pelaku sangat kesal di ejek sehingga pelaku membunuh, dalam hal itu sebagai manusia kita seharusnya mempunyai hati nurani sehingga mempunyai rasa peri kemanusiaan dan adanya rasa kasih. Sebagai bangsa yang adil kita 
juga bisa memiliki rasa keadilan dan mempunyai Tuhan yang maha esa.dari kasus ini juga motif pembunuhan ini megaku sangat kesal diejek atau di hina sehingga pelaku melakukan pembunuhan.

\section{G. Kesimpulan}

Dalam hal ini juga kita dapat pembelajaran tentang beretika moral dan beretika dalam manusia, dalam kasus ini juga kita sebagai umat yang beragama mempunyai hukum yang berlaku di negara kita dalam hal ini juga mengenai hak asasi manusia bahwa membunuh ialah hal yang keji yang di lakukan manusia. Dan dalam hal ini juga pelaku tidak mempunyai hati nurani sehingga pelaku berani membunuh korban, sehingga dalam kasus ini juga pelaku sangat tertekan karena sering di ejek korban malaya dari itu pelaku membunuh korban. Pembelajaran yang bisa kita ambil adalah kita sebagai umat manusia jangan saling membunuh kita sebagai manusia harus saling mengasihi satu sama lainnya. 


\section{Referensi}

https://regional.kompas.com/read/2019/01/30/17160401/motif-pembunuhan$\underline{\text { sadis-di-bima-terungkap-pelaku-mengaku-kesal-sering-diejek?page=all }}$

Dewantara, A. (2017). Diskursus Filsafat Pancasila Dewasa Ini.

Dewantara, A. (2017). Filsafat Moral (Pergumulan Etis Keseharian Hidup Manusia).

DEWANTARA, A. W. (2016). GOTONG-ROYONG MENURUT SOEKARNO DALAM PERSPEKTIF AKSIOLOGI MAX SCHELER, DAN SUMBANGANNYA BAGI NASIONALISME INDONESIA (Doctoral dissertation, Universitas Gadjah Mada).

Dewantara, A. W. (2013). Merefleksikan Hubungan antara Etika Aristotelian dan Bisnis dengan Studi Kasus Lumpur Lapindo. Arete, 2(1), 23-40.

Dewantara, A. (2018). Alangkah Hebatnya Negara Gotong Royong (indonesia Dalam Kacamata Soekarno). 